\title{
The impact of power lines on phytocenoses of the regional reserve "Uporovsky", Tyumen Region, Russia
}

\author{
Elena Popova ${ }^{1, *}$ \\ ${ }^{1}$ Tobolsk complex scientific station UrB RAS, 16, Osipova, St., 626150, Tobolsk, Russia
}

\begin{abstract}
The article reflects the results of anthropogenic impact on phytocenoses of the territory of the Uporovsky regional nature reserve (Uporovsky district, Tyumen region, Russia). On the territory of the Uporovsky regional nature reserve (Uporovsky district, Tyumen region) there is a $110 \mathrm{kV}$ electrical power transmission line (power line) which has the length of 8 kilometers and the right-of-way width of about 30 meters. This power line is undoubtedly the main source of anthropogenic electromagnetic radiation in this area. The degree of participation of individual species in the herbage was determined by taking into account their relative abundance. When exposed to the power lines in the right-ofway area, flora biodiversity decreases due to the loss of a number of species. The effect of electromagnetic fields causes transformation of the vegetation cover, synanthropization and the subsequent complete destruction of natural vegetation. To determine the degree of anthropogenic load on the studied phytocenoses, the synanthropization index is determined. In the synanthropic fraction of the flora, 30 species belonging to 12 families were identified. The synanthropization index of the studied phytocenoses ranges from $6.6 \%$ to $81.2 \%$. The largest number of synanthropic species is observed in the anthropogenic area.
\end{abstract}

\section{Introduction}

At present, the anthropogenic impact on the environment is steadily growing. The installation of high voltage power lines poses a number of environmental, social and economic problems. Among environmental problems, one can single out the effect of electromagnetic fields (EMF) generated by power lines affecting animals and plant organisms that permanently or temporarily inhabit areas where they are exposed to these fields $[1,2]$. Despite the fact that power lines have become an almost mandatory component of landscapes of populated areas, not so many information about direct observations or field work in the area of EMF impact from a specific power line can be found in the literature.

A necessary condition for the normal functioning of ecosystems and the biosphere as a whole is a sufficient level of species diversity. Biological diversity is the basis for maintaining the ecological balance and sustainable development of the biota of regions.

\footnotetext{
*Corresponding author: Popova-3456@mail..ru
} 
One of the forms of preservation of phyto-diversity is a network of specially protected natural reservations. However, these reservations, despite their exclusion from intensive development, also undergo anthropogenic transformation $[3,4]$.

In the center of the Uporovsk district of the Tyumen region (Russia), on the lands of the state forest fund, the Kolos farm and forestry, seven kilometers away from the village of Uporovo, there is the Uporovskiy nature reserve with estimated area of 6,920.0 ha. It was established in 1996 and was reorganized on April 20, 2009, and is currently operational. This is a comprehensive conservation facility of regional rank.

The vegetation cover of this area is represented by pine forests, birch forests with an admixture of aspen. All phytocenoses in this territory belong to the formation of pine forests or birch forests derived from it, birch-pine, pine-birch forests $[5,6]$.

On the territory of the Uporovsky regional nature reserve (Uporovsky district, Tyumen region) there is a $110 \mathrm{kV}$ electrical power transmission line (power line) which has the length of 8 kilometers and the right-of-way width of about 30 meters. The power transmission network is growing steadily due to increased industrial use of electricity. The expansion of the power line network is associated with an increasing multifactorial impact on natural ecosystems. The main sources of anthropogenic radiation in this area are undoubtedly the power lines.

The aim of the study is to assess biodiversity and the level of synanthropization within the power line.

\section{Material and methods}

The northern boundary begins in the northwestern corner of the quarter 22 of the Bunkovsky district forestry of the Uporovo forest district (point 1, coordinates N 56.1452, E 66.0610) and goes north-east along the right side of the Bunkovo-Uporovo road. Not reaching $500 \mathrm{~m}$ to Skorodum village, at the extreme northern point (point 2) with coordinates N 56.1450, E 66.0930 the border turns to the southeast and follows the forest road, crossing the blocks 17, 18, 19, 20, 21 of the Bunkovsky district forestry, to southeastern corner of the quarter 21 of the Bunkovsky district forestry [7].

The eastern border starts in the southeast corner of the quarter 21 of the Bunkovsky district forestry (point 3, coordinates N 56.1310, E 66.1435) and goes to the south-west along the eastern border of the quarter 28 of the Bunkovsky district forestry to its southeast corner. Further south-east along the right side of the forest road in the direction of the Morevo village, to point 4 (coordinates N 56.1141, E 66.1537). Then the border turns to the south and goes to the right bank of the river Emurtla (point 5, coordinates N 56.1015, E 66.1537).

The southern boundary starts on the right bank of the river Emurtla (point 5), goes along the right bank of the river downstream to the west, ends at the point with coordinates $\mathrm{N}$ 56.0945, E 66.0820 (point 6).

The western border starts at point 6 , goes north, $1.5 \mathrm{~km}$ to the bridge near Bunkovo village, the border turns north along a $1.5 \mathrm{~km}$ curve from the southeast, east and north sides around Bunkovo village and overlooks the right side of the road Bunkovo-Uporovo (point

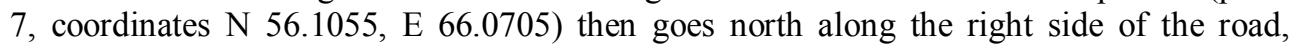
coinciding with the western boundary of block 89 of the Uporovsky rural district forestry, to point 1 (Fig. 1). 


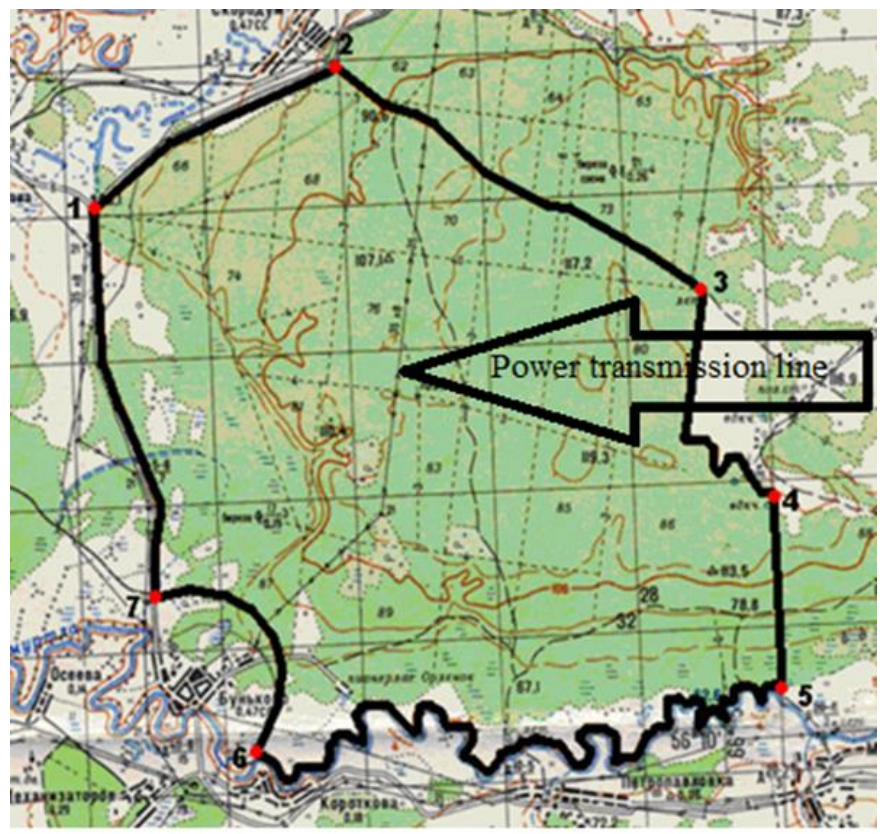

Fig. 1. A schematic map of the regional ranked "Uporovsky" nature reserve (Uporovsky district, Tyumen region).

The vegetation was described during the vegetation seasons of 2019 according to the methodological techniques and approaches adopted in phytocenology and widely used in geobotanical studies $[8,9]$.

To study the components of the studied phytocenoses, transects were laid. Sample collection was geographically limited to their area. The transects represented a rectangle $(500 \times 20 \mathrm{~m})$ in the natural (undisturbed, E) and anthropogenic (right-of-way under the high-voltage power line, A) sections.

To determine the abundance, the Drude scale was used - a system of point-based ocular estimate grades used for assessment of the abundance of the species: soc (socialis) - plants close in on the above-ground part, completely; cop3 (from copiosa - copious) - very copious; cop2 - copious; cop1 - fairly copious; sp (sparsae) - absentmindedly; sol (solitaries) - thin, scattered; un (unicum) - occurs singly [10,11].

To determine the degree of transformation of flora and individual plant communities, we evaluated the synanthropization index - the share of synanthropic species in relation to the total number of species [11].

Assessment of the degree of synanthropization was carried out according to the method of R.I. Burda [12]. The percentage is calculated by the formula (1):

$$
\mathrm{X}=\mathrm{S}_{\mathrm{sp}} / \mathrm{S}_{\mathrm{t} .} \times 100 \%
$$

where $S_{s p}-$ the number of synanthropic species $S_{t}$. the total number of species on the site.

Assessment of the degree of synanthropization according to the five-point system of R. I. Burda [12]:

1 point - the content of synanthropic species at the site is no more than $1 \%$, i.e. they are sparsely interspersed in the general background of vegetation; 2 points - the content of synanthropic species on the site is no more than $10 \%$. Found among several plants that form a mass admixture to the background; 3 points - the content of synanthropes on the site 
is no more than $30 \%$. Here they are found among many species, making up a significant part of the general background; 4 points - the content of synanthropes on the site is no more than $50 \%$, i.e. their dominance is evident. Synanthropes make up the bulk of the vegetation; 5 points - the content of synanthropes on the site is more than $50 \%$. Synanthropic species occupy most of the site, i.e. they dominate, forming a general background in which all other types of vegetation are interspersed.

\section{Results}

An analysis of the revealed floristic composition shows that the plant communities of the studied territory belong to forest formations of the taiga natural zone. In general, in the studied area, south-taiga forests dominate with coniferous species: Picea obovata Ledeb., Abies sibirica Ledeb., Pinus sylvestris L. Such indigenous forests grow on the studied territory in upland areas or on flattened or steeper slopes on well-drained soils of the podzolic series (sod-podzolic), forming primary communities in which the abovementioned tree species act as edificators. An example of this type of forest is the club-moss pine. The forest stand formula is $10 \mathrm{C}$, the canopy density is 0.6 . The community is four-tiered. The first tier is about 27 meters high and is made up by Pinus sylvestris L., the average trunk diameter is 0.5 meters, and the maximum is 0.6 meters. The average age is $120-130$ years. The second tier is made up by Pinus sylvestris L., 12-15 meters high, the average trunk diameter is 0.3 meters (maximum - 0.4 meters). The undergrowth of this community is made up by Picea obovata aged 14-18 years. The herb layer is dominated by Diphasiastrum complanatum (L.) Holub, Fragaria vesca L. The first sub-tier of the herb layer is made up by Antennária dióica (L.) Gaertn., Trifolium lupinaster L., Lathyrus pratensis L., Polygonatum odoratum (Miller) Druce. In the second sub-tier, which is 0.50.6 meters high, Luzula pilosa (L.) Willd., Pulmonaria mollis Wulfen ex Hornem etc. grow. The third sub-tier of the herb layer, which is max. 0.4 meters high is made up by Pyrola rotundifólia L., Viola hirta L.

Thus, in the studied territory, indigenous (primary) communities are essentially steppificated ones with a typical set of southern taiga grasses, shrubs, and subshrubs.

In many sections of the power line in the studied area, the primary forests are replaced by derivative (secondary) forests made up of small-leaved species Betula pendula Roth and Populus tremula L. as a result of clear-cutting. Such forests are at different stages of serai series, and are gradually replaced by indigenous communities, which is facilitated by the lack of constraining development factors, including anthropogenic ones. The new growth of conifers is well developed, which favors the natural course of restoration of native vegetation.

In the smaller open areas that form forest glades, grass and shrub communities are formed, made up by the species of the meadow-edge complex Solidágo virgáurea L., Campanula cervicaria L., Hypericum perforatum L., Dianthus versicolor Fischer ex Link, Carlina biebersteinii Bernh. ex Hornem., Astragalus danicus Retz. with the participation of Calluna vulgaris (L.) Cull, Trifolium lupinaster L., Leucanthemum vulgare L., Achilléa millefólium L., and other species.

The flora of the studied region within the transects, the studied areas of the reserve territory, is composed of 112 species of vascular plants, combined into 24 families, of which 46 species were found in plot E, 29 species in plot A, the remaining 37 species were common to both sites.

The degree of participation of individual species in the herbage is determined by the methods of accounting for their relative abundance. The most common of these methods is the use of the Drude scale, in which various degrees of abundance are indicated by points 
based on the values of the smallest distances between individuals of the species and their occurrence.

On the transects laid, the greatest abundance was noted for plants of the Compositeae family (19 species). Eight species were found that grew on the territory of plot E: Artemisia marschalliana L. (cop 1 ), Artemisia frigida Willd. (sp.), Pilosella officinarum L. (sp.), Serratula coronata L. (sp.), Solidágo virgáurea L. (sp.), Antennária dióica (L.) Gaertn. ( $\left.\mathrm{cop}_{2}\right)$, Inula salicina L. (sp.), Carlina biebersteinii Bernh. ex Hornem. (sp.). In plot A, three species were found that were found only in this plot: Conyza canadensis L. $\left(\operatorname{cop}_{2}\right)$, Erigeron ácer L. (sp.), Cirsium vulgare (Savi) Ten. (sp.). The remaining species were common to the two studied plots (E, A), but with varying degrees of abundance: Artemisia austrica Jacq. (sp., sol.), Artemisia vulgaris L. (un., sp.), Leucanthemum vulgare Lam. (sol., cop 1 ), Senecia jacobea L. (sol., sp.), Gnaphalium sylvaticum L. (sol., sp.), Hieracium umbellatum L. (sol., sp.), Círsium heterophyllum (L.) Hill (sp., sp.), Achilléa millefólium L. (sp., sol.).

The Fabaceae family proved to be abundant. In this family, species were also found that grow only in plot E: Astragalus danicus Retz. (cop 1 ), Astragalus onobrychis L. (sp.), Trifölium aureum Poll. (sp.), Trifolium lupinaster L. (sp.), Vicia tenuifolia Roth. (sp.), Lathyrus pisiformis L. (sp.), Lathyrus humilis (Ser.) Sprengel (sp.), Orobus vernus L. (sp.).

In plot A, Fabaceae are represented by: Medicago falcata L. ( $\left.\operatorname{cop}_{3}\right)$, Medicago lupulína L. ( $\left.\operatorname{cop}_{1}\right)$, Trifolium repens L. (sp.), Trifolium medium L. (sp.), Vicia sepium L. (sp.), Trifolium arvense L. (sp.), Vicia cracca L. (sp.), Lathyrus pratensis L. (sp.).

The Graminea family is represented by twelve species, of which only four are common for plots (E, A): Agrostis tenuis Sibth. (sp., sp.), Agrostis gigantea Roth. (sol., un.), Calamagrostis epigeios (L.) Roth. (sp., cop 3 ), Poa pratensis L.(un., sp.).

Species of Molinia caerulea (L.) Monch. (sp.), Agrostis clavata Trin. (sp.), Brachypodium pinnatum (L.) Beauv (sol.), Calamagrostis arundinacea (L.) Roth (cop 3 ), Phleum pratense L. (sp.) were found in plot E, and Festuca rubra L. (sp.), Festuca pratensis Hudson (sp.), Poa angustifolia L. (sol.) were found in plot (A).

Plants of the Rosaceae family were found on the studied transects. Four species were common for the plots: Potentilla erecta (L.) Raeuschel (cop 3 , sol.), Fragaria vesca L. (sol., $\mathrm{cop}_{3}$ ), Rubus saxatilis L. (sol., cop ${ }_{3}$ ), Rubus melanolasius Levl. (un., sp.). The remaining six species were found only in plot E: Geum urbanum L. (sol.), Potentilla canescens Besser (sol.), Filipendula vulgaris Moench ( $\left.\operatorname{cop}_{3}\right)$, Fragaria viridis Duch. (sol.), Sanguisorba officinalis L. (sp.), Agrimonia pilosa Ledeb. (sp.).

In the Caryophyllaceae family, three species grew in plot E: Dianthus versicolor Fischer ex Link (cop 3 ), Gypsophila altissima L. (sp.), Moehringia lateriflora (L.) Fenzl. (sp.). Four species of this family were found in plot A: Gypsophila muralis L. (sol.), Melandrium album (Miller) Garcke (sol.), Viscaria vulgaris L. (sp.), Scleranthus annuus L. (cop 2 ). Silen nutans L. (sp., sp.), Eremogene saxatilis (L.) Ikonn ( $\mathrm{cop}_{2}$, sp.) were common to all plots.

Veronica spicata L. (sp.), Veronica longifolia L. (sp.), Melampyrum pratense L. (sp.), Digitalis grandiflora Miller $\left(\mathrm{cop}_{3}\right)$ belong to the Scrophylariaceae family. These species were found in plot A. Other species of this family are Verbascum thapsus L. (sp.), Verbascum nigrum L. (sp.) identified in plot E. Veronica chamaedrys L. (sp., cop co, $_{1}$, Melampyrum cristatum L. (sp., $\mathrm{cop}_{2}$ ) grow in all of the studied plots.

The remaining families were represented by one to three species: Ranunculaceae Pulsatilla flavescens (Zucc.) Juz.(cop ${ }_{1}$, sol.), Ranunculus polyanthemos L. (sol., cop con $_{3}$, Trollius europaeus L. (sol., $\mathrm{cop}_{2}$ ); Polygonaceae - Polygonum hydropiper L. (A-cop 2 ), Polygonum aviculare L. (A-cop 2 ); Geraniaceae - Geranium sylvaticum L. (A-sp.), Geranium sibiricum L. (E-sp.); Hypericaceae - Hypericum perforatum L. (E-sp.); Violaceae - Viola hirta L. (sol., sp.), Viola rupestris DC. (sol., sp.); Onagraceae - Epilobium collinum C.C. Gmelin (A-sp.), Chamerion angustifólium (L.) Holub (un., sp.); Umbelliferae - 
Pimpinella saxifraga L. (sol., sp.), Pleurospermum uralense Hoffm. (E- sp.), Heracleum sibiricum L. (A- sol.); Ericaceae - Calluna vulgaris (L.) Cull ( $\left.\operatorname{cop}_{1}, \mathrm{cop}_{3}\right)$, Ledum palustre L. (E-sol.); Pyrolaceae - Chimaphila umbellata (L.) W.Barton (E- sp.), Pyrola rotundifólia L. (E-cop 3 ), Pyrola chlorantha Swartz (E-sp.); Vacciniaceae - Vaccinium vitis-idaea L. (sol., sp.), Vaccinium myrtillus L. (E-sp.); Boraginaceae - Pulmonaria mollis Wulfen ex Hornem (E-cop 3 ); Labiateae - Dracocephalum ruyschiana L. (sol., cop 3 ), Prunella vulgaris L. (sp., cop 3 ); Campanulaceae - Campanula cervicaria L. (sp., cop 3 ), Campanula glomerata L. (sp., cop 2 ); Liliaceae - Lilium pilosiusculum (Freyn ) Miscz. (E- sp.), Polygonatum odoratum (Miller) Druce (E- sp.); Orchidaceae - Epipactis helleborine (L.) Crantz (E-sp.), Platanthera bifólia (L.) L.C.Mrich. ( $\operatorname{cop}_{3}$, sp.); Juncaceae - Juncus compressus Jacq. (sp., cop 3 ), Luzula pilosa (L.) Willd. (E-sp.); Cyperaceae - Carex leporina L. (E-sp.), Carex ericetorum Pollich (E-cop 3$)$, Carex macroura Meinsh (cop ${ }_{3}$, sol.).

To determine the degree of anthropogenic transformation of the flora and individual plant communities, the synanthropization index is determined - the proportion of synanthropic species in relation to the total number of species. In the synanthropic fraction of the flora, 30 species belonging to 12 families were identified. The synanthropization index of the studied phytocenoses is in the range from $6.6 \%$ to $81.2 \%$. The largest number of synanthropic species is found in plot $\mathrm{A}$, the content of synanthropes is more than $50 \%$, the structure is simplified, and productivity and stability of plant communities are changed. The maximum values of the synanthropization index ( 5 points $)$ - according to the five-point system of R. I. Burda, the content of synanthropes in the plot exceeds $50 \%$.

\section{Discussion}

Providing literature data on the reaction of terrestrial plants growing in the areas of electromagnetic fields generated by power lines, many researchers have noted the inhibition of plant production in such areas $[1,2,13,14]$.

It was found that the magnetic field of industrial frequency created by the power lines has a negative effect on living organisms. Plants that grow in buffer (sanitary) zones of power lines are much more likely to have external deformations: enlarged flowers, extra leaves, irregularly shaped stems [15].

One of the indicators of the impact of power line fields can be an estimate of the fluctuating asymmetry of bilateral signs. For plants, this is shown by field and experimental observations at Piriqueta caroliniana (Walter) in Florida [15]. Freeman [14] studied the fluctuating asymmetry of the leaves of the beans of Phaseolus vulgaris L. growing directly under the wires of a power line and at a distance from it. Similar results were obtained for the asymmetry of the leaves of soybean Glycine max L. [16]. Soybean leaves are ternary, which makes it possible to perform multiple measurements on one leaf. Scientists evaluated FA in plants under a $675 \mathrm{kV}$ power line and in plants taken at a distance of 50 and $100 \mathrm{~m}$ from the wire. An analysis of the data showed that the variability of FA does not depend either on the composition of the soil or on the size of the leaves, but depends on the distance to the power line $[17,18,19]$.

Summarizing the impact of power lines on the vegetation of the Uporovsky regional nature reserve, the following direction of such impact should be noted: exposure to power lines decreases biodiversity due to the loss of Artemisia marschalliana L., Artemisia frigida Willd., Pilosella officinarum L., Serratula coronata L., Solidágo virgáurea L., Antennária dióica (L.) Gaertn., Inula salicina L., Carlina biebersteinii Bernh. ex Hornem., Astragalus danicus Retz., Astragalus onobrychis L., Trifōlium aureum Poll., Trifolium lupinaster L., Vicia tenuifolia Roth., Lathyrus pisiformis L., Lathyrus humilis (Ser.) Sprengel, Orobus 
vernus L., Agrostis tenuis Sibth., Agrostis gigantea Roth., Calamagrostis epigeios (L.) Roth., Poa pratensis L. and other species.

The impact of the fields leads to the transformation of the vegetation cover, synanthropization and the subsequent complete destruction of natural vegetation.

\section{Conclusion}

Due to the violation of the integrity of (natural) indigenous communities, synanthropic species settle on the right of way territory, leading to an increase in biodiversity.

The abundance of native species from indigenous communities in the right of way is changing. A number of species, primarily photophilous ones, oppressed in these communities, in open areas of the right of way increase their abundance in the following options: solitaries $\rightarrow$ sparsae; solitaries $\rightarrow$ copiosa; sparsae $\rightarrow$ copiosa. At the same time, shade-loving species reduce abundance from cop $_{3}$ to sol. or do not occur at all on the anthropogenic plot.

In accordance with the established procedure and when required in specially protected natural areas, measures should be taken to restore disturbed biodiversity in ecosystems, for example, translocation of rare and protected species. Plant communities, as the main components of the green cover, are given primary importance, and special attention is paid to understanding the mechanisms of transformation and sustainability of the communities.

\section{References}

1. D. Roux, A. Vian, S. Girard, P. Bonnet, , F. Paladian, E. Davies, G. Ledoigt, Physiologia Plantarum 128, 283-288 (2006)

2. P. Jinapang, P. Prakob, P. Wongwattananard, N.E. Islam, P. Kirawanich, Bioelectromagnetics 31, 519-527 (2010)

3. S. Ellingsrud, A. Johnsson, Bioelectromagnetics 14, 257-271 (1993)

4. V. Mildaziene, G. Pauzaite, A. Malakauskiene, R. Zukiene, Z. Nauciene, I. Filatova, V. Azharonok, V. Lyushkevich, Bioelectromagnetics 37, 536-548 (2016)

5. J.L. García-Corona, J.M. Mazón-Suástegui, H. Acosta-Salmón, S.C. Díaz-Castro, M. P. Amezquita-Arce, C. Rodríguez-Jaramillo, Aquaculture Research 50, 2729-2734 (2019)

6. N. Javed, M. Ashraf, N.A. Akram, F.Al-Qurainy, Photochemistry and Photobiology 87, 1354-1362 (2011)

7. L.V. Shumilova, Botanical geography of Siberia (Publishing house of Tomsk University, Tomsk, 1962)

8. S.K. Cherepanov, Vascular plants of the USSR (Science, Leningrad, 1981)

9. E. Ganebnykh, T. Burtseva, A. Petuhova, A.Mottaeva, , E3S Web of Conferences, 91,08035, (2019) doi.org/10.1051/e3sconf /20199108035

10. N.I. Naumenko, Flora and vegetation of the southern Zuraliy (Kurgan University, Kurgan, 2004)

11. P.V. Kulikov, Identifier of vascular plants of the Chelyabinsk region (UrB RAS, Ekaterinburg, 2010)

12. R.I. Burda, Anthropogenic transformation of flora (House Naukova Dumka, Kiev, 1991) 
13. D.F. Woodward, E. Snyder-Conn, R.G. Riley, T.R. Garland, Archives of Environmental Contamination and Toxicology 17(5), 683-697 (1988)

14. D. Carl Freeman, John H. Graham, Mary Tracy, John M. Emlen, C. L. Alados, International Journal of Plant Sciences 160, 157-166 (1999)

15. P. Cuevas-Reyes, K. Oyama, A. González-Rodríguez, G. Wilson Fernandes, L. Mendoza-Cuenca, Journal of Tropical Ecology 27(4), 383-391 (2011)

16. M. Veličković, T. Savić, Plant Biosystems - An International Journal Dealing with all Aspects of Plant Biology 144(3), 692-702 (2010)

17. F. Aloulou, M. Kallell, H. Belayouni, Environmental Forensics 12(3), 290-299 (2011)

18. J.R. Milligan, R.A. Krebs, K.M. Tarun, International Journal of Plant Sciences 169(5), 625-630 (2008)

19. H. Zhang, X. Wang, Frontiers of Biology in China 1(4), 411-417(2006) 